\title{
Complete Palmer Lunate Enucleation: A Rare Sport Injury
}

\author{
Elyazid Houass", M. R. Elgaliou, M. A. Haouzi, M. Boufetal, R. A. Bassir, M. Kharmaz, M. O. Lamrani, M. S. Berrada
}

\section{Departement of Orthopedic Surgery and Trauma, Ibn Sina University Hospital Center Rabat, Morocco}

Faculty of Medecine and Pharmacy-University Mohamed V Rabat, Morocco

DOI: $10.36347 /$ sjams.2021.v09i03.031

| Received: 24.02.2021 | Accepted: 08.03.2021 | Published: 25.03.2021

*Corresponding author: Elyazid Houass

Abstract

Complete palmer lunate enucleation as the end stage of a perilunate dislocation is a very uncommon injury, especially in sports practice, it is associated with high rate of osteonecrosis. These usually occur after high-energy trauma of the wrist. We report a case of a complete palmar lunate enucleation occuring while practicing sport, he underwent an early open reduction through a single dorsal approach and internal fixation with K-wires along with ligamentous repair. The patient regained near full range of movement at 16 weeks post operatively, there were no instances of infection or avascular necrosis.

Keywords: palmer lunate enucleation, uncommon injury, sports practice, K-wires, ligamentous repair.

Copyright $(\odot) 2021$ The Author(s): This is an open-access article distributed under the terms of the Creative Commons Attribution 4.0 International License (CC BY-NC 4.0) which permits unrestricted use, distribution, and reproduction in any medium for non-commercial use provided the original author and source are credited.

\section{Patient And ObServation}

A 21-year-old right-handed man presented to the emergency department with a history of fall on his hyperextended right wrist while practicing biking, There was pain and swelling around the wrist. The movements at the wrist were painful and restricted. There was no neurovascular deficit especially of median nerve. The radiographs (Figure-1) revealed an acute palmar lunate enucleation without scaphoid fracture.

With no further complications later and There was no evidence of avascular necrosis or degenerative change.

The patient underwent an open reduction of the dislocation. With a dorsal approach to the wrist joint between the 3rd and 4th extensor compartments, the perilunate dislocation was reduced and fixed with three $\mathrm{K}$-wires through scapholunate, triquetrolunate and capitatolunate junctions. The reduction was confirmed under $\mathrm{C}$ arm intraoperatively (Figure-2). The scapholunate ligament and dorsal capsule was meticulously sutured and the joint was immobilized. The patient was encouraged to actively move the fingers immediately postoperatively.

The K-wires were removed after six weeks and the patient was put on physiotherapy sessions. The patient was followed up at regular intervals and his recent radiograph at the completion of nine months showed satisfactory alignment of the carpal bones and no recurrence of the dislocation. Clinically, the patient recovered near normal range of movements at the wrist joint by the end of four months.

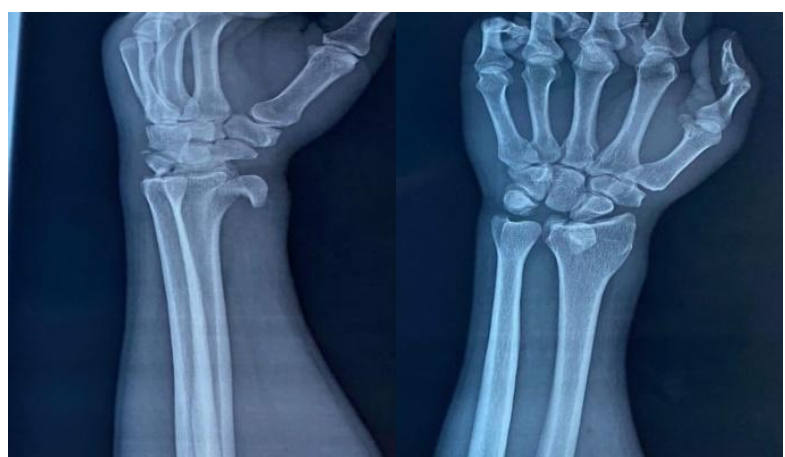

Fig-1: A conventional AP and lateral wrist x-ray revealing a palmer lunate enucleation

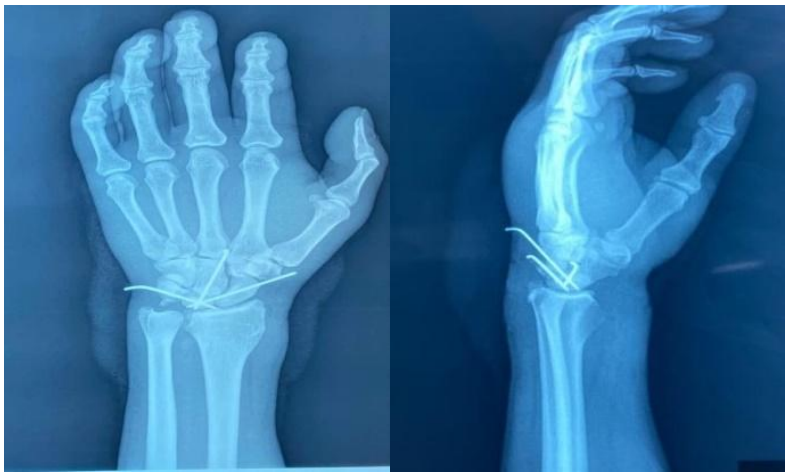

Fig-2: A postoperative conventional AP and lateral wrist $x$ ray confirming the reduction of the dislocation fixed with three $K$ wires through scapholunate, triquetrolunate and capitatolunate junctions 


\section{DISCUSSION}

Volar dislocation of the lunate was first described by Green and O'Brien in 1978 [1]. It is a rare type of carpal dislocation [2].

The most common mechanism of this injury is fall onto a hyperextended wrist with or without the forearm in supination [3].

In a volar lunate dislocation (the final stage of perilunate injury), the capitate has reduced from its dorsally dislocated position to become colinear with the radius, dislocating the lunate into the carpal tunnel.[4] Lunate dislocations are further classified as stage IIA when the lunate has subluxated out of its fossa but has rotated $<90^{\circ}$; stage IIB injuries exhibit lunate rotation $>90^{\circ}[5]$.

Perilunate dislocations are commonly missed injuries either due to lack of careful clinical examination at the time of initial presentation or due to delayed presentation by the patient [6]. The prognosis for these injuries with delayed presentation, is poor compared with those that are treated immediately [7-9].

Adequate clinical history and careful physical examination will help in early detection of these injuries [10]. Careful scrutiny of radiographs is essential with attention to the Gilula's arc of the carpal joints, scapholunate interval, scaphocapitate and capitolunate angles [11]

Closed reduction is technically difficult and most authors suggest that immediate ORIF followed by ligament repair (if possible) is the treatment of choice $[12,13]$. Combined dorsal and volar surgical approach to the wrist joint has usually been advocated for the management of this injury [14]. However, single dorsal approach helps to preserve the palmar wrist ligaments to the maximum with minimal surgical soft tissue damage [15]. Various implants have been used for stabilisation of the dislocation after reduction such as compression screws, cerclage wires and K-wires [14, $15]$.

In our case, we treated by open reduction and internal fixation with percutaneous $\mathrm{K}$-wires via a single dorsal approach.

\section{Concluion}

Perilunate dislocations although rare, Early diagnosis and treatment is necessary to prevent the potential risk of avascular necrosis of the carpa, with open reduction and internal fixation with $\mathrm{K}$-wires via a dorsal approach to abtain the best of results.

\section{REFERENCES}

1. Green DP, O'Brien ET. Open reduction of carpal dislocations: indications and operative techniques. J Hand Surg [Am]. 1978;3:250-65.

2. Papadonikolakis A, Mavrodontidis A, Zalavras C, Hantes M, Soucacos P. Transscaphoid volar lunate dislocation: a case report. J Bone Joint Surg [Am]. 2003; 85-A:1805-8

3. Aitken AP, Nalebuff EA. Volar transnavicular perilunar dislocation of the carpus. J Bone Joint Surg Am. 1960 Sep; 42-A:1051-7

4. Stanbury SJ, Elfar JC. Perilunate dislocation and perilunate fracture-dislocation. JAAOS-Journal of the American Academy of Orthopaedic Surgeons. 2011 Sep 1;19(9):554-62.

5. Herzberg G, Comtet JJ, Linscheid RL, Amadio PC, Cooney WP, Stalder J: Perilunate dislocations and fracturedislocations: A multicenter study. J Hand Surg Am. 1993;18(5):768-779.

6. Pappas ND, Lee DH. Perilunate injuries. Am J Orthop. 2015 Sep 1;44(9):E300-2.

7. Howard FM, Dell P. The unreduced carpal dislocation: a method of treatment. Clin Orthop. 1986;202:112-16.

8. Gellman HG, Schwartz SD, Botte MJ, Feiwell L. Late treatment of a dorsal trans-scaphoid, transtriquetral perilunate wrist dislocation with avascular changes of the lunate. Clin Orthop. 1988; 237:196-203.

9. 9 Siegert JJ, Frassica FJ, Amadio PC. Treatment of chronic perilunate dislocations. J Hand Surg [Am]. 1988;13:206-12

10. Subramanian K, Arora B, Bhatnagar A, Jan I. Perilunate Dislocation-Case Report and Review of Literature. Journal of clinical and diagnostic research: JCDR. 2017; 11(8), RD06.

11. Givissis P, Christodoulou A, Chalidis B, Pournaras J. Neglected trans-scaphoid transstyloid volar dislocation of the lunate. Late result following open reduction and $\mathrm{K}$-wire fixation. J Bone Joint Surg Br. 2006 May; 88(5):676-80.

12. Baulot E, Perez A, Hallonet D, Grammont PM. Scaphoid and lunate palmar divergent dislocation. Apropos of a case. Rev Chir Orthop Reparatrice Appar Mot. 1997;83:265-9.

13. Komura S, Yokoi T, Suzuki Y. Palmar-divergent dislocation of the scaphoid and the lunate. J Orthop Traumatol. 2011;12:65-8.

14. Trumble T, Verheyden J. Treatment of isolated perilunate and lunate dislocations with combined dorsal and volar approach and intraosseous cerclage wire. J Hand Surg Am. 2004 May; 29(3):412-7.

15. Malović M, Pavić R, Milosević M. Treatment of trans-scaphoid perilunate dislocations using a volar approach with scaphoid osteosynthesis and temporary Kirschner wire fixation. Mil Med. 2011 Sep; 176(9):1077-82. 